\title{
Study on Mindset, Locus of Control and Self Esteem of Children with Specific Learning Disabilities
}

\author{
Pallavi Sahu1, Dr. G. Shri Krishna², Surya Prakasham³ \\ ${ }^{1}$ M.Phil (Rehabilitation Psychology), Consultant Psychologist (St. Peter's Public School) \\ ${ }^{2}$ Lecturer (Dept of Rehabilitation Psychology), NIEPID
}

${ }^{3}$ Statistician, NIEPID

\begin{abstract}
The aim of the present study is to investigate the relationship among mindset, locus of control and self esteem of children with specific learning disabilities. The target population of the study is composed of students with specific learning disabilities. Total selected sample were 69.Out of 69, 52 were boys and 17 were girls. The age groups of students ranged from 10 years to 15 years. Children were chosen from $4^{\text {th }}$ std to $10^{\text {th }}$ std. To gather the required data, three scales were used.1) Implicit theory of Intelligence Scale and Implicit Theory of Personality Scale (Carol Dweck, 2000), 2) Rosenberg Self Esteem Scale, 3) Nowicki-Strickland Locus of Control Scale for Children. Results showed significant difference between mindset and self esteem among children with specific learning disabilities. Result also showed highly significant difference in locus of control with respect to educational level of the children with specific learning disabilities. Correlation Matrix indicated significant negative relationship among two sets of variables; 1) Significant negative correlation between locus of control and self esteem and 2) Significant negative correlation between fixed mindset and self esteem. Once we are aware of the mindset we hold, we can change it with the help of strategies involved to develop growth mindset. It can further help educators to train children towards growth mindset as fixed mindset could act as a hindrance in the overall development of the child.
\end{abstract}

Keywords: Mindset, Locus of control, Self esteem, Specific Learning Disabilities

\section{Introduction}

Mindsets are beliefs we hold about ourselves and our beliefs most likely determine our actions. Concept of mindset has been established after decades of research work by renowned Psychologist Carol Dweck from Stanford University. Mindset refers to implicit theories that individuals hold regarding the nature of intelligent behavior. Individuals who attribute intelligence to fixed traits, they hold a "fixed" theory of intelligence (that is, a fixed mindset). A person with fixed mindset believes that qualities are fixed and it can't be changed and these believe create an urgency to prove them over and over. Some of them are trained in this mindset from an early age. Most of them have goal of proving themselves-in the classroom, in their careers, and in their relationships too. Every situation is looked for the confirmation of their intelligence, personality, or character. Every situation is evaluated. Will we look smart or dumb? Will we be accepted or rejected? Will we feel like a winner or a loser? Will we succeed or fail? And there are those who attribute intelligence to learning, effort, training, and practice. They hold a "growth" theory of intelligence (that is, a growth mindset). Person with growth mindset is not afraid of failure. They are always ready to learn, and to face challenges. People with growth mindset don't believe that anyone can be anything rather they have an insight into their true abilities so they don't waste their time in proving themselves and to gain approval. They judge their potential in an appropriate manner and they act accordingly. They have a passion for learning. Passion for stretching beyond and sticking to it, even when it's not going well, is the hallmark of the growth mindset.
This mindset allows people to thrive during the most challenging times in their lives. It was believed that IQ test was meant to summarize children's unchangeable intelligence. In fact, it was not. Alfred Binet believed that education and practice could bring about fundamental change in intelligence. In his major book, "Modern Ideas About Children", he summarized his work with hundreds of children with learning difficulties. He mentioned, "A few modern philosophies assert that an individual's intelligence is a fixed quantity, a quantity which cannot be increased. We must protest and react against this brutal pessimism. With practice, training, and above all, method, we manage to increase our attention, our memory, our judgment and literally to become more intelligent than we were before.'

Carl Rogers has done an extensive work in the area of the self. Carl Rogers (1959) believed that the self-concept has three different components:

1) The view you have of yourself (self-image)

2) How much value you place on yourself (self-esteem or self-worth)

3) What you wish you were really like (ideal-self)

Self-esteem (also known as self-worth) refers to the extent to which we like, accept or approve of ourselves, or how much we value ourselves. Self-esteem always involves a degree of evaluation. We may have either a positive or a negative view of ourselves. Campbell and Sedikides (1999) carried out a meta analysis of studies on self serving bias. In line with the bias, success was attributed to internal factors. However, failure was sometimes attributed to internal factors and sometimes to external factors. Self esteem tends to rise when

Volume 8 Issue 4, April 2019 www.ijsr.net 


\section{International Journal of Science and Research (IJSR) \\ ISSN: 2319-7064}

ResearchGate Impact Factor (2018): 0.28 | SJIF (2018): 7.426

we experience success or praise. A person who is competent and effective and who is loved, admired, and respected by others will almost always have high self esteem (Baumeister et al,2003).Genuine self esteem is based on an accurate self evaluation of our strengths and weaknesses. A positive self evaluation that is bestowed too easily may not be healthy (Twenge \&Campbell, 2001).

Adolescents who see themselves as deviating from the ideal physique can quickly lose their self esteem. The changes in the social environment notably the high school experience, which poses a host of challenges can play havoc with self esteem, they are required to adapt to a changing cadre of teachers rather than to a single one.Furthermore, they must respond to increasingly heavy academic demands which, if not met, change the view that family and peers have of the student's potential (Skolnick,1986). Thus, early adolescence may be particularly critical period in the continuing effort waged throughout life to maintain a sense of self esteem. Well adjusted people have some appreciation of their own worth and feel accepted by those around them. They are comfortable with other people and are able to react spontaneously in social situations. At the same time, they do not feel obligated to completely subjugate their opinions to those of the group.

Julian Rotter gave the concept of Locus of Control (LOC) in the 1950s (Rotter 1966). He states that an individual has an internal locus of control if one perceives that the event is contingent upon one's behavior or relatively permanent characteristics, whereas external locus of control is characterized by the belief that event is perceived as not being contingent upon one's own action. Construct given by Rotter was Locus of Control of Reinforcement. Rotter's view was that behavior was largely guided by reinforcements (rewards and punishments) and through contingencies such as rewards and punishments; individuals come to hold beliefs about what causes their actions. These beliefs, in turn, guide what kinds of attitudes and behaviors people adopt. Philip Zimbardo also believed that "A locus of control orientation is a belief about whether the outcomes of our actions are contingent on what we do (internal control orientation) or on events outside our personal control (external control orientation)." (Zimbardo, 1985). Locus of control is a concept that has a significant effect on our daily lives. Those with an external locus of control believe that their own actions do not influence future outcomes. This makes individual less likely to work to reach their full potential due to the motivational, emotional, and cognitive deficits it creates. In fact, people with an external locus of control are more likely to suffer from depression and other ailments because they believe their actions cannot improve their current position. Individuals with an internal locus of control view events as resulting from their own actions. Persons with an external locus of control view events as being under the control of external factor such as luck (Marsh \& Weary, 1995). Those with an internal locus of control see the world through a more adaptive perspective. They believe that hard work and personal abilities will lead to positive outcomes. Locus of control is generally viewed as inborn personality constructs but it's not only inborn personality component but also the childhood experiences that determine the belief plays a vital role. Children raised by parents who encouraged their independence and helped them to learn the connection between actions and their consequences tend to have a better developed internal locus of control. In case of children with learning disabilities, problems in academics is paramount due to which many of them, most likely enter the state of helplessness about the low score and in turn, blame the school system while others blames themselves and feel stressed due to low score.

Some individuals, despite having an average or above average level of intelligence, have real difficulty in acquiring basic academic skills. These skills include those needed for successful reading, writing, listening, speaking and/or math. These difficulties might be due to specific learning disabilities. According To PWD Act 2016,"specific learning disabilities means a heterogeneous group of conditions wherein there is a deficit in processing language, spoken or written, that may manifest itself as a difficulty to comprehend, speak, read, write, spell, or to do mathematical calculations and includes such conditions as perceptual disabilities, dyslexia, dysgraphia, dyscalculia, dyspraxia and developmental aphasia."

According to DSM-V, Specific learning disorder is a developmental disorder that begins by school-age, although it may not be recognized until later. It involves ongoing problems related to learning key academic skills; including reading, spelling, written expression and/or math. Specific learning disorder is not simply a result of lack of instruction or poor instruction. Children with specific learning disorder are sometimes described as having unexpected academic underachievement because the child's test scores or grades does not match with the thinking and reasoning ability. In their preschool years, children with specific learning disorder often experience delays in speech and language skills. Learning difficulties are seen by the early school years in most children. However, for some the learning difficulties may not be apparent until later, when academic demands are greater. Specific learning disorder can only be diagnosed after formal education starts. Kindergarten-age children with specific learning disorder may not be able to recognize and write letters, may have trouble breaking down spoken words into syllables and may have trouble recognizing words that rhyme. Children in elementary school may have difficulty connecting letters with sounds, may read slowly and inaccurately, and may have difficulty with spelling, written expression or math basics. Adolescents and adults may still read slowly with much effort and may have problems with writing, understanding what they read or with mathematical problem solving. Adolescents and adults may avoid activities that demand reading or arithmetic (reading for pleasure, reading instructions).They may use alternative approaches to access print (e.g., text-to-speech/speech-to-text software, audio books, and audiovisual media).

\section{Objective of the Study}

1) To assess the mindset, locus of control and self esteem of children with specific learning disabilities (SLD).

2) To find out the relationship among mindset, locus of control (LOC) and self esteem of children with specific learning disabilities.

\section{Volume 8 Issue 4, April 2019 www.ijsr.net}




\section{International Journal of Science and Research (IJSR) \\ ISSN: 2319-7064}

ResearchGate Impact Factor (2018): 0.28 | SJIF (2018): 7.426

3) To compare mindset, locus of control and self esteem with respect to gender and educational level (class) of children with specific learning disabilities.

\section{Methodology}

The sample consisted of 69 children with specific learning disabilities. The age group ranged from 10 years to 15 years. Children were chosen from $4^{\text {th }}$ std to $10^{\text {th }}$ std.Purposive sampling was used to select participants for the study. Inclusion Criteria: Children with Specific Learning Disabilities Exclusion Criteria Children who have learning problems which are primarily the result of visual, hearing, or motor handicaps, intellectual disability, emotional disturbance, or environmental, cultural and economic disadvantage. The data was collected from St. Peter's Public School, St.Peter's High School, Total Solutions (Resource Centre for Children with Learning Difficulties) located in Secunderabad.

\subsection{Tools Used}

1) Implicit Theory of Intelligence scale and Implicit Theory of Personality Scale

2) Rosenberg Self Esteem Scale

3) Nowicki-Strickland Locus of Control Scale for Children

\subsection{Procedure}

\subsubsection{Data Collection Procedure \\ Step 1}

Consent letter was submitted in schools as well as at Total Solution. Informed consent was taken from the head of both the organization. In School, signed consent letter was shown to the concerned block incharges. $\left(5^{\text {th }}\right.$ std, $6^{\text {th }}-7^{\text {th }}$ std and $8^{\text {th }}-$ $10^{\text {th }} \mathrm{std}$ ). Those whose were already assessed were selected from the list. List of students were also taken from block incharges of all the "A" section (special section) of various classes. Students in the list were assessed on Malin's Intelligence Scale for Children (MISIC), Diagnostic Test for Learning Disability (DTLD), Schonell Spelling Test (B), Schonell Graded Word Reading Test and Roswell Chall Diagnostic Reading test to rule out any other conditions.

\section{Step 2}

Appropriate time was chosen to call selected participants to fill the forms in School. (Free period or prior permission to utilize one class for participants to fill the form as per the instruction given). At Total Solution, forms were given to those students who were already assessed. Once participants filled the consent form they were requested to fill in the forms as per the instruction given. Firstly, scale to assess the mindset was given followed by other two scales. Participants from $5^{\text {th }}$ std were called individually. Questions were read and explained for children with reading difficulty. No prompt or in no way any option was shown as preferred option. Participants from $6^{\text {th }}$ and $7^{\text {th }}$ std were given forms as a group of five each.They were instructed to be seated away from each other. Seating arrangement was taken care of to make sure that they were not influencing each other's response. Participants' from $8^{\text {th }}$ std were called in group of 5 each.Initially,total number of participants selected from this particular block was 27 but only 16 participants were taken, as other students were busy with drama fest practice at that time.

\section{Step 3}

Forms were collected and participants were assured of confidentiality of their responses.

\section{Results and Discussion}

Based on the objective of the study the following 9 null hypotheses have been drawn

1) There would be no significant relationship between mindset and locus of control.

2) There would be no significant relationship between mindset and self esteem.

3) There would be no significant relationship between locus of control and self esteem.

4) There would be no significant difference in mindset, locus of control and self esteem with respect to educational level of the children with specific learning disabilities.

4.1 There would be no significant difference in mindset with respect to educational level of the children with specific learning disabilities.

4.2 There would be no significant difference in locus of control with respect to educational level of the children with specific learning disabilities.

4.3 There would be no significant difference in self esteem with respect to educational level of the children with specific learning disabilities.

5) There would be no significant difference in mindset, locus of control and self esteem with respect to gender of the children with specific learning disabilities.

5.1 There would be no significant difference in mindset with respect to gender of the children with specific learning disabilities

5.2 There would be no significant difference in locus of control with respect to gender of the children with specific learning disabilities

5.3 There would be no significant difference in self esteem with respect to gender of the children with specific learning disabilities

To analyze the data, SPSS software has been used.

Table 1: Frequency Distribution

\begin{tabular}{|c|c|c|c|}
\hline & & Frequency & Percent \\
\hline \multirow{2}{*}{ Educational level } & $5^{\text {th }}-7^{\text {th }}$ & 45 & $65.2 \%$ \\
\cline { 2 - 4 } & $8^{\text {th }}-10^{\text {th }}$ & 24 & $34.8 \%$ \\
\hline \multirow{2}{*}{ Gender } & Boys & 52 & $75.4 \%$ \\
\cline { 2 - 4 } & Girls & 17 & $24.6 \%$ \\
\hline \multirow{2}{*}{$\begin{array}{c}\text { Locus of control } \\
\text { (LOC) }\end{array}$} & Average & 17 & $24.6 \%$ \\
\cline { 2 - 4 } Mindset & External & 52 & $75.4 \%$ \\
\hline \multirow{2}{*}{$\begin{array}{c}\text { Fixed } \\
n\end{array}$} & Growth & 38 & $55.1 \%$ \\
\cline { 2 - 4 } & \multicolumn{2}{|c}{} \\
\hline
\end{tabular}

\section{Volume 8 Issue 4, April 2019 www.ijsr.net}




\section{International Journal of Science and Research (IJSR) \\ ISSN: 2319-7064}

ResearchGate Impact Factor (2018): 0.28 | SJIF (2018): 7.426

Table 1 shows the frequency distribution of educational level, gender, locus of control and mindset. Study on gender ratio for reading difficulties by Jesse L. Hawke, Richard K.Olson et al. found that the prevalence of reading difficulties is typically higher in boys than girls in both referred and research-identified samples. In present study, 52 boys were selected as compared to 17 girls. It also indicates that $55.1 \%$ of students showed fixed mindset and $44.9 \%$ students showed growth mindset. In present study, none of the students showed internal locus of control. Out of 69, 52 showed external locus of control.

Table 2: Mean and SD of Self Esteem

\begin{tabular}{|c|c|c|c|c|c|}
\hline Self esteem & N & Min. & Max. & Mean & SD \\
\hline SE-score & 69 & 21 & 36 & 28.52 & 3.407 \\
\hline
\end{tabular}

Table 2 shows the mean and standard deviation of self esteem. Obtained mean value is 28.52 and obtained standard deviation value is 3.407 .

Table 3: Comparison of Mindset VS Locus of Control

\begin{tabular}{|c|c|c|c|}
\hline \multirow{3}{*}{ Mindset } & & \multicolumn{2}{|c|}{ Locus of Control } \\
\cline { 2 - 4 } & Fixed & Average & External \\
\cline { 2 - 4 } & Growth & $32.4 \%$ & $81.6 \%$ \\
\hline \multicolumn{2}{|c|}{ Chi-Square Test : 1.76, df $=1, \mathrm{p}>0.05$, not sig } \\
\hline
\end{tabular}

Null Hypothesis 1 states that there would be no significant relationship between mindset and locus of control. Table 3 shows the comparison of mindset VS locus of control. It shows that $18.4 \%$ with fixed mindset falls under average locus of control while $32.3 \%$ with growth mindset falls under average locus of control. It also shows that $81.6 \%$ with fixed mindset exhibit external locus of control while $67.7 \%$ with growth mindset exhibit external locus of control. Student with growth mindset are very less likely externally motivated has been supported by a study done by Betsy $\mathrm{Ng}$ on the Neuroscience of Growth Mindset and Intrinsic Motivation. It aimed to shed light on the relationship between growth mindset and intrinsic motivation in terms of supporting a growth mindset to facilitate intrinsic motivation through neural responses. According to Dweck, teaching growth mindset to junior high school students resulted in increased motivation and better academic achievement. Her findings revealed that students in the growth mindset intervention group outperformed those in the control group (who received excellent training in study skills), indicating improved learning and desire to work hard. A learner with a growth mindset tends to self-regulate their own learning and has the propensity to cope with academic tasks. Hence, encouraging a growth mindset can improve the academic performance of college students and middle school math students. The study by Moser et al. suggested that individuals with a growth mindset are receptive to corrective feedback, exhibiting a higher Pe (error positivity) waveform response, which is correlated with a heightened awareness of and attention to mistakes. Enhanced Pe amplitude was associated with enhanced attention to corrective feedback following errors and subsequent error correction. Individuals with growth mindset are likely to have heightened awareness of and attention to errors. In addition, growth-minded individuals may neutralize the affective response to negative feedback, which could be indicated by neural activation.
Null Hypothesis 2 states that there would be no significant relationship between mindset and self esteem. Table 4 shows comparison of self esteem vs mindset. Result suggests that students with fixed mindset showed lower self esteem as compared to students with growth mindset. Student with fixed mindset seeks approval. They are afraid of failure so, they prefer not to explore anything new which can challenge their already established level of intelligence. Such students, most likely suffer from low self esteem due to lack of exploration.

Table 4: Comparison of Self Esteem VS Mindset/ Locus of Control (LOC)

\begin{tabular}{|c|c|c|c|c|c|c|c|}
\hline \multicolumn{2}{|c|}{} & $\mathrm{N}$ & Mean & SD & t-value & $\mathrm{p}$ \\
\hline \multirow{2}{*}{$\begin{array}{c}\text { Self } \\
\text { Esteem } \\
\text { Score }\end{array}$} & Mindset & Fixed & 38 & 27.82 & 3.254 & \multirow{2}{*}{1.98} & $\mathrm{p}<0.05$ \\
\cline { 2 - 9 } & Growth & 31 & 29.39 & 3.442 & & \\
\cline { 2 - 8 } & $\begin{array}{c}\text { Locus of } \\
\text { Control }\end{array}$ & Average & 17 & 29.47 & 3.105 & \multirow{2}{*}{1.33} & $\mathrm{p}>0.05$ \\
\cline { 3 - 7 } & External & 52 & 28.21 & 3.472 & & \\
\hline
\end{tabular}

Null Hypothesis 3 states that there would be no significant relationship between locus of control and self esteem. Table 4 also shows the comparison between self esteem and locus of control. Even though it is not significant, trend is moving towards the expected direction that is, student with external locus of control would exhibit lower self esteem as compared to average locus of control. The correlation matrix results showed that there is a significant negative correlation between self esteem and LOC.

Table 5: Comparison of Educational level VS Mindset/LOC

\begin{tabular}{|c|c|c|c|}
\hline \multirow{3}{*}{ Educational Level } & & \multicolumn{2}{|c|}{ Mindset } \\
\cline { 2 - 4 } & $5^{\text {th }}-7^{\text {th }}$ & $62.2 \%$ & $37.8 \%$ \\
\cline { 2 - 4 } & $8^{\text {th }}-10^{\text {th }}$ & $41.7 \%$ & $58.3 \%$ \\
\hline Chi-Square test: $2.673, \mathrm{df}=1, \mathrm{p}>0.05$, not sig \\
\hline & & \multicolumn{2}{|c|}{ Locus of Control } \\
\hline \multirow{2}{*}{} & \multicolumn{2}{|c|}{ Average } & External \\
\hline \multirow{2}{*}{ Educational Level } & $5^{\text {th }}-7^{\text {th }}$ & $13.3 \%$ & $86.7 \%$ \\
\cline { 2 - 4 } & $8^{\text {th }}-10^{\text {th }}$ & $45.8 \%$ & $54.2 \%$ \\
\hline Chi-Square test : 8.904, df $=1, \mathrm{p}<0.01$, highly significant \\
\hline
\end{tabular}

Null Hypothesis 4.1 states that there would be no significant difference in mindset with respect to educational level of the children with specific learning disabilities. Table 5 shows the comparison of mindset with respect to educational level. Result showed that $62.2 \%$ student from $5^{\text {th }}-7^{\text {th }}$ std showed fixed mindset as compared to $41.7 \%$ student from $8^{\text {th }}-10^{\text {th }}$ std. Result suggests that more student at lower educational levels show fixed mindset. Table also indicates that $37.8 \%$ of students from $5^{\text {th }}-7^{\text {th }}$ std showed growth mindset while $58.3 \%$ student from $8^{\text {th }}-10^{\text {th }}$ std showed growth mindset. The result shows that higher the educational level more the inclination towards growth mindset, that is, students at higher classes are more likely to be intrinsically motivated, which perhaps might be exploration of new pattern.

Null Hypothesis 4.2 states that there would be no significant difference in locus of control with respect to educational level of the children with specific learning disabilities. Table 5 also shows the comparison of locus of control with respect to educational level. Result showed that $86.7 \%$ students from $5^{\text {th }}-7^{\text {th }}$ std exhibit external locus of control while $54.2 \%$ students from $8^{\text {th }}-10^{\text {th }}$ std exhibit external locus of control. Average locus of control is shown by $13.3 \%$ of

Volume 8 Issue 4, April 2019 www.ijsr.net

Licensed Under Creative Commons Attribution CC BY 


\section{International Journal of Science and Research (IJSR) \\ ISSN: 2319-7064}

ResearchGate Impact Factor (2018): 0.28 | SJIF (2018): 7.426

students from $5^{\text {th }}-7^{\text {th }}$ std while $45.8 \%$ students from $8^{\text {th }}-10^{\text {th }}$ std showed average locus of control. Result obtained is highly significant. Result suggests that orientation of locus of control can be determined by the level of education. Lower the educational level (lower class level / age), more the inclination towards external locus of control. People are more intrinsically motivated as they grow. Various studies have found a strong relationship between educational level and locus of control. In one such study done by Marvin W.Boss and Maurice C.Taylor on the relationship between locus of control and academic level and sex of secondary school students, the relationships among locus of control, academic program, and sex of grade 9 secondary school students were investigated. Two hundred sixty-seven high school students from advanced, general, and basic level programs were administered the modified forms of the Nowicki-Strickland Locus of Control Scale for Children and the Intellectual Achievement Responsibility Questionnaire. As hypothesized, students in the advanced level program were more internally controlled than either general or basic level students. As well, advanced level students were more internally responsible for their intellectual-academic failures than general level students.

Table 6: Comparison of Self Esteem VS Educational Level

\begin{tabular}{|c|c|c|c|c|c|}
\hline & Educational Level & $\mathrm{N}$ & Mean & SD & t-value \\
\hline \multirow{2}{*}{$\begin{array}{c}\text { Self Esteem } \\
\text { Score }\end{array}$} & $5^{\text {th }}-7^{\text {th }}$ & 45 & 28.67 & 3.169 & \multirow{2}{*}{.481} \\
\cline { 2 - 5 } & $8^{\text {th }}-10^{\text {th }}$ & 24 & 28.25 & 3.870 & \\
\hline
\end{tabular}

$\mathrm{df}=67, \mathrm{p}>0.05$, not sig.

Null Hypothesis 4.3 states that there would be no significant difference in self esteem with respect to educational level of the children with specific learning disabilities. Table 6 shows comparison of self esteem with respect to educational level. Mean score of self esteem with respect to educational level $5^{\text {th }}-7^{\text {th }}$ std is 28.67 and standard deviation is 3.169.Mean score of self esteem with respect to educational level 8 th $-10^{\text {th }}$ std is 28.25 and standard deviation is 3.870 .

Null hypothesis 5.1 states that there would be no significant difference in mindset with respect to gender of the children with specific learning disabilities. Table 7 shows that $55.8 \%$ boys as compared to $52.9 \%$ girls show fixed mindset traits while $44.2 \%$ boys as compared to $47.1 \%$ girls shows growth mindset. Result suggests that boys are more likely to possess fixed mindset traits than girls and girls are more likely to possess growth mindset traits.

Table 7: Comparison of Gender VS Mindset/LOC

\begin{tabular}{|c|c|c|c|}
\hline & & \multicolumn{2}{|c|}{ Mindset } \\
\hline & & Fixed & Growth \\
\hline \multirow{2}{*}{ Gender } & Boys & $55.8 \%$ & $44.2 \%$ \\
\cline { 2 - 4 } & Girls & $52.9 \%$ & $47.1 \%$ \\
\hline \multicolumn{2}{|c|}{ Chi-Square Test : 0.41 ,df $=1, \mathrm{p}>0.05$,not sig } \\
\hline & & \multicolumn{2}{|c|}{ Locus of Control } \\
\hline \multirow{2}{*}{ Gender } & & Average & External \\
\cline { 2 - 4 } & Boys & $26.9 \%$ & $73.1 \%$ \\
\cline { 2 - 4 } & Girls & $17.6 \%$ & $82.4 \%$ \\
\hline \multicolumn{2}{|c|}{ Chi-Square Test :0.594,df $=1, \mathrm{p}>0.05$, not sig } \\
\hline
\end{tabular}

Null Hypothesis 5.2 states that there would be no significant difference in locus of control with respect to gender of the children with specific learning disabilities. Table 7 also shows the comparison of locus of control with respect to gender. Result showed that $26.9 \%$ of boys showed average locus of control as compared to $17.6 \%$ of girls who showed average locus of control. $73.1 \%$ of boys showed external locus of control as compared to $82.4 \%$ of girls who showed external locus of control. Result suggests that girls showed more external locus of control as compared to boys. Michael L.Wehmeyer did a study on gender differences in locus of control scores for students with learning disabilities. Study examined gender differences on locus of control scores for students with learning disabilities. Scores from two measures of locus of control, the adult version of the Nowicki-Strickland Internal-External Scale and the Intellectual Achievement Responsibility Questionnaire, were compared for 77 boys and 27 girls. Significant differences were found by gender on the Nowicki-Strickland inventory. On all assessments girls' means were more external than boys.

Table 8: Comparison of Self Esteem VS Gender

\begin{tabular}{|l|c|c|c|c|c|}
\hline & Gender & $\mathrm{N}$ & Mean & SD & t-value \\
\hline \multirow{2}{*}{ Self esteem Score } & boys & 52 & 28.52 & 3.122 & \multirow{3}{*}{} \\
\cline { 2 - 5 } & girls & 17 & 28.53 & 4.274 & -.011 \\
\hline
\end{tabular}

$\mathrm{df}=67, \mathrm{p}>0.05$, not sig.

Null Hypothesis 5.3 states that there would be no significant difference in gender with respect to self esteem of the children with specific learning disabilities.

Table 8 shows the mean and standard deviation with respect to gender. Two highly influential lines of past research have established that self-esteem is higher in men than in women (Kling et al., 1999) and that self-esteem increases from adolescence to middle adulthood (Orth \& Robins, 2014). Samuel D. Gosling in 2016 did a study on age and gender differences in self-esteem. It was a Cross-Cultural study. Results suggested that men tend to have higher self-esteem than women do, and both gender show age graded increases in self-esteem from late adolescence to middle adulthood .Both males and females who feel physically attractive tend to have higher self-esteem (e.g., Feingold, 1994).Yet numerous studies have shown that girls' attitudes about their appearance become more negative during adolescence (Harter, 1993). This decline in girl's perceived physical attractiveness is supposed to have particularly negative effects on self-esteem when cultural pressures regarding women's physical appearance are high (Brumberg, 1997; Kling et al., 1999).

Table 9: Correlation Matrix (Mindset, Locus of Control, Self Esteem)

\begin{tabular}{|c|c|c|}
\hline Variable $(\mathrm{X})$ & Variable $(\mathrm{Y})$ & Pearson $\mathrm{r}$ \\
\hline Locus of control & Fixed mindset & 0.160 \\
\hline Locus of control & Growth mindset & 0.009 \\
\hline Locus of control & Self esteem & $\mathbf{- 0 . 2 5 8}^{*}$ \\
\hline Fixed mindset & Growth mindset & 0.202 \\
\hline Fixed mindset & Self esteem & $\mathbf{- 0 . 3 6 1}^{* *}$ \\
\hline Growth mindset & Self esteem & 0.135 \\
\hline
\end{tabular}

Result indicated that there is a significant negative correlation between locus of control and self esteem, (Pearson $r$ 0.258*). Higher the locus of control (higher scores exhibit external locus of control) lower the self esteem. Fixed mindset and self esteem are also found to be highly significant with Pearson $\mathrm{r}\left(-0.361^{* *}\right)$. Result also

\section{Volume 8 Issue 4, April 2019}




\section{International Journal of Science and Research (IJSR) \\ ISSN: 2319-7064}

ResearchGate Impact Factor (2018): 0.28 | SJIF (2018): 7.426

shows that there is significant negative correlation between fixed mindset and self esteem. More the fixed mindset, lower the self esteem. Reda Abouserie did a study in 2006 on sources and levels of stress in relation to locus of control and self esteem in University Students. Results indicated a significant positive correlation between locus of control and academic stress, suggesting that students with external beliefs are more stressed than those with internal. A significant negative correlation between self esteem and both academic and life stress emerged, indicating that students with high self esteem are less stressed than are those with low.

\section{Conclusion}

The result of the present study leads to following conclusions.1) There is a significant difference between mindset and self esteem among children with specific learning disabilities. If person possess fixed mindset then there is a strong likelihood that he/she would exhibit lower self esteem. Fixed mindset oriented people believe that ability/intelligence/personality are fixed traits. Hence, they don't make an attempt at anything which challenges their beliefs. Most likely, they would not raise their hand in class due to the fear of being ridiculed for not knowing while on the other hand, people with growth mindset would not be afraid of ridicule as they believe in learning and for them, effort is more valuable than ability. If children are taught about mindset in schools then they would be in a better position to face the world with confidence and higher self esteem.2) There is a highly significant difference between educational level and locus of control. Higher the education level, more the likelihood of internal locus orientation. When we are young, we find it difficult to accept our mistakes and prefer to put blame for our mistakes on external factors (external locus orientation). Gradually, as we grow, we tend to understand the value of taking responsibility for our mistakes henceforth; gradually, we learn to take responsibilities for our actions (Internal LOC). Children with specific learning disabilities mostly exhibit lower self esteem. They are unable to cope like others of same age group children in same class so; they try to hide their shortcomings by putting blame on external factors mostly. In such situations, they exhibit external LOC.3) Locus of control and self esteem are found to be inversely related. Higher score of locus of control exhibit external locus of control hence, more the locus of control, lower the self esteem. Children with specific learning disabilities tries to mask their shortcoming by putting blame on fate, luck or external factors hence, they are most likely to show lower self esteem.4)There is a significant negative correlation between fixed mindset and self esteem that is, both are inversely related to each other.5)Result showed that not a single student with specific learning disabilities exhibited internal locus of control.6)Though not significant, trend showed that more the fixed mindset, more the external locus of control.

There are several limitations to this study. Scales used for data collection were difficult to comprehend with immediacy. Help was provided to read the statements as many of the participants faced difficulty in reading and comprehending simultaneously. Due to time constraints at school and worry about missing classes, students might have hurried to give responses. As data collection were limited to three organizations ( 2 schools and 1 resource centre), results could not be generalized. Teaching style, school environment varies from setting to setting. Socio economic status of the children, parenting style were not considered, which might have indirectly played a role in the development of particular mindset, locus of control orientation and in development of self esteem. Number of children who availed remedial intervention had not been explored. It might have affected the result.

There are perhaps various strengths of the present study. Mindset as a concept has not been explored much and none of the study have been found which has attempted to study mindset, locus of control and self esteem together. Sample size is large-69. It is not only a study to find the relationship among mindset, locus of control and self esteem of children of specific learning disabilities, it will also help to provide growth intervention to those children who showed fixed mindset to deal effectively with challenges in daily life. There could be numerous implications. Concept of mindset has its implication in education sector, relationships, and work sector. Knowledge about mindset changes the meaning of effort, failure, and insight. People's ideas about risk and effort grow out of their basic mindset, once we are aware of the mindset we hold; we can change it with the help of strategies involved to develop growth mindset. It can improve the achievement motivation among children which will help them to be less fearful of failure. They would be willing to learn just to learn, not to only win.

The study perhaps should be repeated in future with a larger sample. Effectiveness of growth mindset should be explored. As Mindset is an upcoming concept, workshops and seminars should be conducted to make people aware about concept of mindset and its importance. Schools should be targeted to conduct training program for teachers on how to develop a growth mindset because if teacher is oriented then she/he would be able to help children to be aware of their mindset and how to develop growth mindset. Parents training program should be conducted to create awareness about what praise most likely does to a child's mindset and whether it is advisable to praise a child for his ability. Study can be replicated to normal population. Immense amount of research work is required in the area of mindset to help educators, parents to inculcate growth mindset effectively and to help professional to use the most effective strategies for growth mindset intervention. In-depth knowledge of concept of mindset and its implementation for effective and smart living is essential.

\section{References}

[1] Abouserie, R.(2006). Sources and Levels of Stress in Relation to Locus of Control and Self Esteem in University Students. Journal of Educational Psychology :

An International Journal of Experimental Educational Psychology, 14(3), 323-330. Retrieved from https://doi.org/10.1080/0144341940140306 


\section{International Journal of Science and Research (IJSR) \\ ISSN: 2319-7064}

ResearchGate Impact Factor (2018): 0.28 | SJIF (2018): 7.426

[2] Atkinson \& Hilgard et al. (2004) Introduction to Psychology (14th edition), International student edition, Thomson \& Wadsworth. 529.

[3] Blackwell,L. S., Trzesniewski,K.H., Dweck, C. S. (2007) Implicit Theories of Intelligence to Predict Achievement Across an Adolescent Transition: A Longitudinal Study and an Intervention. Journal of Child Development, 78(1), 246 - 263. DOI: 10.1111/j.1467-8624.2007.00995

[4] Bleidoen, W., Arslan, R.C., Denissen, Jaap.J.A., Rentfrow, P.J.,Gebauer, J.E.,Potter, J.,Gosling, S.D.(2016). Age and Gender differences in selfesteem-a cross-cultural window. E-Journal of Personality and Social Psychology, 111(3), 396-410. Retrieved from http://dx.doi.org/10.1037/pspp0000078

[5] Boss, M.W., Taylor, M.C (1989). The relationship between locus of control and academic level and sex of secondary school student. Journal of Contemporary Educational Psychology.14 (4), 315-322. Retrieved from https://doi.org/10.1016/0361-476X(89)90018-0

[6] Buchanan, A. \& Kern, M. L. (2017). The benefit mindset: The psychology of contribution and everyday leadership. International Journal of Wellbeing, 7(1), 111. DOI:10.5502/ijw.v7i1.538

[7] Castella,K.D., Byrne,D.G.(2015). My intelligence may be more malleable than yours: the revised implicit theory of intelligence (self-theory) scale is a better predictor of achievement, motivation, and student disengagement. Journal of European Journal of Psychology of Education, 30(3). DOI: 10.1007/s10212015-0244-y

[8] Castella, K.D., Byrne,. D.G., Covington, M.(2013). Unmotivated or Motivated to Fail? A Cross-Cultural Study of Achievement Motivation, Fear of Failure, and Student Disengagement. E-Journal of Educational Psychology, 105(3):861-880. DOI: 10.1037/a0032464

[9] Coon, D., Mitterer, J.O. (n.d) Psychology: Modules for Active Learning, Eleventh edition. International student edition, Thomson \&Wadsworth

[10] Cosden, M., Elliott, K, Noble,S.(1999).SelfUnderstanding and Self-Esteem in Children with Learning Disabilities, E Journal of Learning Disability Quarterly ,Sage publications,22(4) 279-290. Retrieved from https://doi.org/10.2307/1511262

[11]Da, Fonseca. D., Schiano,L.,S, Cury.F, Poinso, F., Rufo, M., Therme, P. (2007).Validation study of the implicit theories of intelligence scale. E-Journal of clinical and biological psychiatry. 33(4):579-84.Elsevier. DOI: ENC-9-2007-33-4-C1-0013-7006-101019-200730045

[12] Diagnostic and Statistical Manual of Mental Disorders (DSM-5), (2013). (Fifth Edition), American Psychiatric Association.

[13] Dr.Dweck, C.S. (2017). Mindset: Changing the way you think to fulfil your potential. Robinson.[14] DudleyMarling CC, Snider V, Tarver SG. (1982). Locus of control and learning disabilities: a review and discussion. E-Journal of Pubmed, NCBI, 54(2):50314. DOI:10.2466/pms. 1982.54.2.503.

[14] Dweck C. (2014).Teacher's Mindsets: "Every student has something to teach me". Educational Horizons, SAGE Journals, 93(2), 10-15, https://doi.org/10.1177/0013175X14561420
[15] Dwyer,C., Dweck,C,.(n.d) Using Praise to Enhance Student Resilience and Learning Outcomes: Helping students 'bounce back' in the face of difficulties. American Psychological Association, retrieved from http://www.apa.org/education/k12/using-praise.aspx

[16] Dvorak,A.E.(2014).Student mindset compared to performance on the Nebraska State Accountability Test (Master's Thesis).University of Nebraska(Lincoln).Retrieved from https://digitalcommons.unl.edu/aglecdiss/101/

[17]Elias,M.J.(2013).Social and Emotional Learning: Refocusing students: how to get their attention back. edutopia. Retrieved from https://www.edutopia.org/blog/implement-sel-at-yourschool-elias-leverett-duffell-humphrey-stepney-ferrito

[18] Eysenck, M, W (2009) Fundamentals of Psychology. Psychology press.

[19] Froedge, K.L. (2017). The Effect of a Growth Mindset on Student Achievement Among Students with a Disability. (Doctoral Dissertation, Western Kentucky University). $\quad$ Retrieved from https://digitalcommons.wku.edu/diss/118

[20] Haimovitz, K., Dweck, C.S. (2016). "Parents' Views of Failure Predict Children's Fixed and Growth Intelligence Mind-Sets". Sage Journal, Psychological science.27 (6), 859-869. https://doi.org/10.1177/0956797616639727

[21] Hartmann,G.M.(2013). The relationship between mindset and students with specific learning disabilities. (Doctoral Dissertation, Humboldt State University). Retrieved from http://hdl.handle.net/2148/1654

[22] Hosseini,S.N., Alavijeh,M.M., Matin,B.K., Hamzeh, B., Ashtarian,H., Jalilian,F.(2016). Locus of Control or Self-Esteem; which one is the Best Predictor of Academic Achievement in Iranian College Students. Iranian Journal of Psychiatry and Behavioral Sciences, 10(1). DOI: $10.17795 /$ ijpbs-2602

[23] Kagan, J., Segal, J. (1992) Psychology: An introduction (seventh edition). Harvard University Harcourt Brace Jovanovich College Publishers, 603-604,669.

[24] Kiral, E. (2015). The relationship between locus of control and perfectionism perception of the primary school administrators - Journal of Procedia -Social and Behavioral Sciences, 174(2015) 3893 - 3902. DOI: 10.1016/j.sbspro.2015.01.1130

[25] Lackey, Christopher J. (2014). Relationships between Motivation, Self-Efficacy, Mindsets, Attributions, and Learning Strategies: An Exploratory Study. (Master's Dissertation, Illinois State University) Retrieved from https://eric.ed.gov/?id=ED569872 Lessons/PN9F$\mathrm{RVzQKeT5A/mindset-carol-s-dweck} \mathrm{retrieved} \mathrm{from}$ https://www.tes.com/

[26] Ng, B. (2018). The Neuroscience of Growth Mindset and Intrinsic Motivation. Journal of Brain science, $\begin{array}{lll}\text { Pubmed.gov } & \text { NCBI, } & \text { 8(2), }\end{array}$ DOI: $10.3390 /$ brainsci8020020

[27] Nowicki, S., \& Strickland, B. R. (1973). A locus of control scale for children. Journal of Consulting and Clinical Psychology, 40(1), 148-154. Retrieved from http://dx.doi.org/10.1037/h0033978

[28] Popova, M. (2017).Fixed Vs. Growth: The Two Basic Mindsets that shape our lives. Retrieved from

\section{Volume 8 Issue 4, April 2019} www.ijsr.net 


\section{International Journal of Science and Research (IJSR) \\ ISSN: 2319-7064}

ResearchGate Impact Factor (2018): 0.28 | SJIF (2018): 7.426

http://www.brainpickings.org/2014/29/carol-dweckmindset/

[29]Raj,F.(2010).Breaking Through: A Handbook for Parents and Teachers with Specific Learning Disabilities. VIFA Publication.

[30] Rhew,E.A.(2017). The effects of a growth mindset intervention on self-efficacy and motivation of adolescent special education students. (Doctoral Dissertation, Western ConnecticutStateUniversity).Retrievedfromhttp://reposit ory.wcsu.edu/educationdis/6

[31]Smith, C.R. (2003). Learning Disabilities: The Interaction of Students and their Environment.5th Edition. Pearson and A. 30, 31.

[32] Sriram, R. (2014). Rethinking Intelligence: The Role of Mindset in Promoting Success for Academically HighRisk Students-Journal of college student retention: research, Theory \& Practice, 15(4),515-536.Retrieved from https://eric.ed.gov/?id=EJ1076282

[33] Storek, J. Furnham, A.(2013).Gender, ' $g$ ', and fixed versus growth intelligence mindsets as predictors of self-estimated Domain Masculine Intelligence (DMIQ).E-Journal of Learning and Individual Differences, 25, 93-98.Retrieved from https://doi.org/10.1016/j.lindif.2013.03.007

[34] Swanson, H.L., Cooney, J. B., John K., Bernice, Wong, Y.L. (2004). Learning Disabilities and Memory (Chapter 2), Learning about Learning Disabilities, Third Edition, Elsevier Academic press.

[35] Truax,M. L.(2017). The Impact of Teacher Language and Growth Mindset Feedback on Writing Motivation. E-Journal of literacy research and instruction, 57 (2), 135-157. DOI: 10.1080/19388071.2017.1340529

[36] Wehmeyer, M.L. (1993). Gender Differences in Locus of Control Scores for Students with Learning Disabilities. Sage Journal Perceptual and Motor Skills, 77(2), 359-366.Retrieved from https://doi.org/10.2466/ pms.1993.77.2.359

[37] Wilkins, Boozer.P.B (2014). Efficacy of a Growth Mindset Intervention to Increase Student Achievement. (Doctoral dissertation,Gardner webb university). Retrieved https://digitalcommons.gardnerwebb.edu/education_etd/ 24

[38] Wilson, D. (2015).Brain Based Learning: strategies for getting and keeping the brain's attention. edutopia. Retrieved from https://www.edutopia.org/blog/strategies-gettingkeeping-brains-attention-donna-wilson-marcus-conyers

[39] Wilson, D., Conyers, M.(2017). Growth Mindset: Helping struggling students build a growth mindset. edutopia. Retrieved from https://www.edutopia.org/article/helping-strugglingstudents-build-growth-mindset-donna-wilson-marcusconyers

[40]ValÅs,H.(1999).Students with Learning Disabilities and Low-Achieving Students: Peer Acceptance, Loneliness, Self-Esteem, and Depression. E-Journal of Social Psychology of Education, 3: 173-192. Retrieved from https://doi.org/10.1023/A:1009626828789

[41]Yearger, David,S., Romero,Casrissa.et al.(2016).Using design thinking to improve psychological interventions: The case of the growth mindset during the transition to high school. EJournal of Educational Psychology.108(3): 374-391. DOI: $10.1037 /$ edu0000098

Volume 8 Issue 4, April 2019 www.ijsr.net 